\title{
Dietary iron intake, serum ferritin and haemoglobin levels, and cognitive development scores of infants aged 6-8 months
}

\author{
Dian Kusumadewi, ${ }^{1}$ Saptawati Bardosono, ${ }^{1}$ Rini Sekartini ${ }^{2}$ \\ ${ }^{1}$ Nutrition Department, Faculty of Medicine, University of Indonesia, Jakarta, Indonesia \\ ${ }^{2}$ Child Health Department, Faculty of Medicine, University of Indonesia, Jakarta, Indonesia
}

\begin{abstract}
Abstrak
Latar belakang: Defisiensi besi selama masa kanak-kanak dapat menimbulkan pengaruh buruk pada fungsi kognitif dan perkembangan psikomotor. Penelitian ini bertujuan mengetahui kadar feritin serum dan hemoglobin dan hubungannya dengan skor perkembangan kognisi pada usia 6-8 bulan.

Metode: Rancangan penelitian potong lintang digunakan pada 76 bayi yang diperoleh dari beberapa Posyandu terpilih di kelurahan Kampung Melayu, kecamatan Jatinegara, Jakarta yang memenuhi kriteria penelitian. Data yang dikumpulkan meliputi usia, berat, panjang, lingkar kepala, asupan zat iron, feritin serum, haemoglobin dan skor perkembangan kognitif dengan menggunakan Capute Scales method (Cognitive Adaptive Test/ Clinical Linguistic Auditory Milestone Scales/ CAT-CLAMS).

Hasil: Dari 74 bayi usia 6-8 bulan yang menjadi subyek penelitian ini, 73\% mempunyai asupan zat besi kurang dari AKG (7 mg/hari), 18,9\% mempunyai kadar feritin serum kurang dari normal (20 $\mu \mathrm{g} / \mathrm{L})$, dan 56,7\% mempunyai kadar hemoglobin kurang dari normal $(11 \mathrm{mg} / \mathrm{dL}$ ). Terkait dengan skor perkembangan kognitif, ditemukan skor CAT yang lebih rendah secara bermakna pada subyek dengan kadar hemoglobin $<11 \mathrm{mg} / \mathrm{dL}(\mathrm{p}=0,026)$.

Kesimpulan: Sebagai upaya pencegahan dini terhadap gangguan perkembangan kognitif, disarankan agar sejak usia 6 bulan mulai memperhatikan asupan zat besi dari makanan pendamping ASI agar tidak terjadi penurunan kadar hemoglobin. (Med J Indones 2011; 20:46-9)
\end{abstract}

\begin{abstract}
Background: Iron deficiency during infancy may lead to negative effect on cognitive function and psychomotor development. This study aimed to investigate serum ferritin, haemoglobin level and its relation to cognitive development score in infants aged 6-8 months.

Methods: This cross-sectional study was done on 76 infants recruited from several selected community health center in Kampung Melayu Village, Jatinegara Jakarta who had fulfilled the study criteria. Data collected consist of age, weight, height, head circumference, energy, protein and iron intake, serum feritin levels, haemoglobin levels and cognitive development score using Capute Scales method (Cognitive Adaptive Test/ Clinical Linguistic Auditory Milestone Scales/ CAT-CLAMS).

Results: Among 74 infants aged 6-8 months, 73\% had less dietary iron intake as compared to its RDA (7 mg/d), $18.9 \%$ were with serum ferritin less than normal value $(20 \mu \mathrm{g} / \mathrm{L})$, and $56.7 \%$ with haemoglobin levels less than normal value $(11 \mathrm{mg} / \mathrm{dL})$. In relation to cognitive development score, this study revealed that the CAT score was significantly lower among subjects with hemoglobin value less than $11 \mathrm{mg} / \mathrm{dL}(\mathrm{p}=0.026)$.

Conclusion: Early prevention of impaired cognitive development is urgently needed by providing iron-rich complementary foods to infants since 6 months (mo) old to maintain the normal level of hemoglobin. (Med J Indones 2011; 20:46-9)
\end{abstract}

Key words: cognitive score, ferritin, hemoglobin, infants

Iron deficiency anemia (IDA) is still remaining a global nutritional problem all over the world ${ }^{1}$ especially in developing countries, including Indonesia. The Survei Kesehatan Rumah Tangga (SKRT) (Household health survey) 2001 stated that IDA in Indonesia is as high as $61.3 \%$ among less than 6 -mo old infants and $64.8 \%$ in 6-11 mo infants. Survey done by Indonesian pediatricion association 2004 found that among 4-12-mo infants in Matraman district-Jakarta, 38\% had anemia and $73 \%$ had iron deficiency. ${ }^{2}$

Correspondence email to:tatibardo@yahoo.com
Infants' iron status is affected by many factors including food intake, physiology (low birth weight), and environment factors (socio-demographic background). Depletion of iron storage can be identified using specific indicators, such as serum ferritin level. However, hemoglobin level is a parameter commonly measured to detect anemia, although it can not specifically find out the cause of the anemia. ${ }^{3}$

During infancy, IDA if not being treated properly will result in negative effects on cognitive function and 
in psychomotor development interference. Infants with IDA have impaired psychomotor development and would have even low psychomotor and mental development compared to infants with iron deficiency but not (yet) being anemic. ${ }^{4}$ Black et al. also stated that micronutrient supplementation consisting of iron and zinc each $20 \mathrm{mg}$ every week for six months had an advantage in motoric development. ${ }^{5}$ Faber et al. ${ }^{6}$ found that infants at the age of 6-12 mo, who consumed $40 \mathrm{~g}$ porridge fortified with $11 \mathrm{mg}$ of iron every day for six months would have an increase in their iron status and developmental scores.

This study aims to investigate dietary iron intake, serum ferritin and hemoglobin levels and their relation to cognitive development score among infants aged 6-8 mo in Kampung Melayu Village, Jatinegara district Jakarta Timur.

\section{METHODS}

\section{Subjects}

The subjects were infants aged 6-8 months recruited from several selected community health center in Kampung Melayu during November 2009 to February 2010 who met the study criteria: 1) male and female infants aged 6-8 months, 2) having normal gestational age and birth weight, 3) apparently healthy, and permitted by the mothers as the respondents to participate in this study.

\section{Study design}

The study used a cross-sectional design to determine the correlation between cognitive development score and dietary iron intake, serum ferritin and hemoglobin levels.

\section{Data collection}

Interview with the respondents was conducted to obtain data concerning the characteristics of subjects and respondents, to find out the infants' intake from breast feeding and complementary feeding using the 24-hour food recall and a one month semiquantitative FFQ to assess the adequacy of iron intake among the research subjects. ${ }^{7}$ In addition to interview, the respondents were also asked to fill out a questionnaire on cognitive development scores with Capute Scales methode (Cognitive Adaptive Test/ Clinical Linguistic Auditory Milestone Scales/ CAT-CLAMS) ${ }^{8}$
Subject's weight and height were measured twice to obtain the average measure. Nutritional status indicator was analyzed using WHO anthro 2005 program. ${ }^{9}$

The laboratory examinations performed include the assessment of hemoglobin and serum ferritin levels. The sample of blood was drawn from the cubiti region which was disinfected using alcohol $70 \%$ before the $1.5 \mathrm{ml}$ of venous blood was drawn. The hemoglobin level was assessed using HemoCue method by placing two drops of blood in the microcuvette. After the microcuvette was completely filled, it was placed to the HemoCue photometer. After several seconds, numbers indicating hemoglobin levels would appear to be recorded. The remaining venous blood was then placed to a vacutainer and sent to Prodia laboratory to assess the serum ferritin level using a method of Elisa. ${ }^{10,11}$

\section{Statistical analysis}

All statistical analyses were performed using SPSS for windows version 11.5. Data were expressed as mean \pm SD for normally distributed data and median (minimum-maximum) for the non-normally distributed data. Normality of the data distribution was checked using Kolmogorov-Smirnov test before further analysis. Based on the results of normality tests, relationships between dietary iron, serum ferritin and hemoglobin levels to cognitive development score were performed using independent-t test or Mann-Whitney U. Power of the study was 0.90 based on assumption to be able to have mean difference of $10 \%$ and probability for type I error $\alpha=0.05 .{ }^{12}$

\section{RESULTS}

\section{Subjects of the study}

There were 74 subjects participating in this study. Data on the characteristics of the subjects include sex and age and were furthermore collected from anthropometric measurements and blood assessment. Cognitive development score was determined as the outcome of the study.

Subjects consisted of 46 (66.2\%) boys and 28 (33.8\%) girls with median age of 6.79 mo. The median weight was $7.4 \mathrm{~kg}$, the average of length was $67.70 \pm 3.13 \mathrm{~cm}$, and head circumference $43.21 \pm 1.56 \mathrm{~cm}$, as shown in Table 1. 
Tabel 1. Characteristics of infants under the study $(n=74)$

\begin{tabular}{lc}
\hline Variables & value \\
\hline Sex, $\mathrm{n}(\%):$ & $49(66.2)$ \\
$\quad$ Male & $25(33.8)$ \\
$\quad$ Female & $6.79(6.02-8.81)$ \\
Age in months, median (min-max) & $7.4(5.35-14.50)$ \\
Weight in kg, median (min - max) & $67.70 \pm 3.13$ \\
Length in cm, mean \pm SD & $43.21 \pm 1.56$ \\
Head circumference in cm, mean $\pm \mathrm{SD}$ & \\
\hline
\end{tabular}

\section{Iron status}

Table 2 shows that the median of dietary iron was 3.82 $\mathrm{mg} / \mathrm{d}$ ranging from $0.42 \mathrm{mg} / \mathrm{d}$ to $14.4 \mathrm{mg} / \mathrm{d}$. This study revealed that 54 of the subjects $(73 \%)$ had dietary iron intake less than its RDA for Indonesian infants aged 7-12 mo $(7 \mathrm{mg} / \mathrm{d})$. The median serum ferritin level of the subjects was $42.3 \mathrm{mg} / \mathrm{L}$ ranging from $2.37 \mathrm{mg} / \mathrm{L}$ to $333 \mathrm{mg} / \mathrm{L}$. Fourteen subjects $(18.9 \%)$ had serum ferritin level less than $20 \mathrm{mg} / \mathrm{L}$ as the cut-off of its normal value. The median of hemoglobin values found in this study was $10.80 \mathrm{mg} / \mathrm{dL}$ ranging from $7.60 \mathrm{mg} /$ $\mathrm{dL}$ to $13.80 \mathrm{mg} / \mathrm{dL}$. This study revealed that 42 subjects (56.8\%) had hemoglobin value less than $11 \mathrm{mg} / \mathrm{dL}$, the cut-off for anemic status for infants.

Table 2. Cognitive score, iron intake, serum ferritin and hemoglobin level of the subjects $(n=74)$

\begin{tabular}{lc}
\hline \multicolumn{1}{c}{ Variables } & Value \\
\hline Cognitive score, median $(\min -\max )$ & $107.5(75.7-148.0)$ \\
CAT score, median $(\min -\max )$ & $114.25(85.7-185.7)$ \\
CLAMS score, median $(\min -\max )$ & $3.82(0.42-14.4)$ \\
Dietary iron in mg, median $(\min -\max )$ & $62(4.2-193.33)$ \\
$\%$ of iron requirement, median $(\min -\max )$ & $54(73)$ \\
$<$ RDA $(7 \mathrm{mg} /$ day $), \mathrm{n}(\%)$ & $20(27)$ \\
${ }^{3}$ RDA, $\mathrm{n}(\%)$ & $42.3(2.37-333.0)$ \\
Serum ferritin in mg/L, median $(\min -\max )$ & $8(10.8)$ \\
Iron deficiency & $6(8.1)$ \\
Iron depletion & $60(81.1)$ \\
Normal & $10.80(7.60-13.80)$ \\
Hemoglobin concentration, median $(\min -\max )$ & $8(10.8)$ \\
Moderate anemia & $34(45.9)$ \\
Mild anemia & $32(43.2)$ \\
Normal &
\end{tabular}

\section{Cognitive development status}

Cognitive development status was determined using CAT and CLAMS scores. Table 2 shows that the median of CAT-score was 107.5 with values ranging from 75.7 to 148.0. The median of CLAMS-score was 114.25 and values ranged from 85.7 to 185.7 . To be able to see factors related to the cognitive development scores, this study analyzed whether the CAT-CLAMS scores differed in relation to the iron status of each subject, i.e. dietary iron, serum ferritin and hemoglobin status.

Table 3 shows that the CAT score did not significantly different in relation to the dietary iron and serum ferritin status, however, the score was significantly higher ( $\mathrm{p}=0.026$ ) among subjects having hemoglobin value $\geq 11 \mathrm{mg} / \mathrm{dL}$. This study did not show any significant difference in the relation between CLAMS score and dietary iron, serum ferrtin and haemoglobin status.

Table 3. Relationships between cognitive development score (CAT) and dietary iron intake, serum ferritin and haemoglobin levels

\begin{tabular}{lcc}
\hline Variables & $\begin{array}{c}\text { Cognitive development } \\
\text { score (CAT) }\end{array}$ & p-value \\
\hline Dietary iron & (mean \pm SD) & 0.419 \\
$<7 \mathrm{mg} /$ day & $109.11 \pm 13.36$ & (independent-t test) \\
$>7 \mathrm{mg} /$ day & $106.04 \pm 117.01$ & \\
Serum ferritin levels & (median, min-max) & 0.590 \\
$<20 \mathrm{mg} / \mathrm{dL}$ & $103.95(86-131.4)$ & (Mann-Whitney U) \\
$>20 \mathrm{mg} / \mathrm{dL}$ & $107.75(75.7-148)$ & \\
Haemoglobin levels & $($ median, min-max) & $\mathbf{0 . 0 2 6}$ \\
$<11 \mathrm{mg} / \mathrm{dL}$ & $101.85(76.6-138)$ & (Mann-Whitney U) \\
$>11 \mathrm{mg} / \mathrm{dL}$ & $113.15(75.7-148)$ & \\
\hline
\end{tabular}

\section{DISCUSSION}

This study found that in general, iron status in terms of dietary iron intake, serum ferritin and haemoglobin levels were less than normal. This cross-sectional study also shows a significant dependence of cognitive development CAT-score on hemoglobin status.

This study shows that the average of dietary iron intake of the subjects from breastmilk and complementary foods was lower than its RDA $(7 \mathrm{mg} / \mathrm{d})$ and $73 \%$ of the subjects had low dietary iron intake. Theoretically, dietary iron intake is related to iron content in breastmilk and complementary foods, increased requirement in relation to the rapid growth during infancy, iron malabsorption, and other pathological conditions. ${ }^{1}$ The low dietary iron intake found in this study was in accordance with the fact that breastmilk for the age of 6-8 months infants will only provide approximately $0.03 \mathrm{mg} / \mathrm{dL}$ or 4.32 $\mathrm{mg} / \mathrm{d}$ if receiving 6 times $240 \mathrm{~mL}$ breastmilk/d. Thus, among infants aged 6 mo and over, there is a need to have supplemented dietary iron from iron-rich 
complementary foods..$^{13}$ Dietary iron intake is needed after the age of 6 months because infants' iron reserve which is about $75 \mathrm{mg}$ is only sufficient to meet iron needs for the first 6 months of life. During infant's life, iron deficiency is strongly related to developmental delays and abnormal behavior in later years. Besides dietary iron intake, iron status can be determined by measuring serum ferritin levels in addition to hemoglobin.

The finding on serum ferritin level in this study shows that the median is still above $20 \mathrm{mg} / \mathrm{L}$, the cut-off for iron depletion/deficiency status. However, it has to be considered that serum ferritin levels can also be elevated when an infant had infection or inflammatory conditions. This study tried to eliminate these conditions by selecting apparently healthy infants as subjects. Actually, serum ferritin level correlates with total-body iron. ${ }^{1}$

With respect to the effect of low dietary iron intake on haemoglobin levels, this study found that the average hemoglobin value was less than $11 \mathrm{mg} / \mathrm{dL}$, the cut-off for low hemoglobin level or anemic status. Accordingly, more than $50 \%$ of the subjects were classified anemic. Regarding to the fact that anemia is mostly caused by iron deficiency, this finding has to be cautiously related to the important role of iron in brain development, i.e. cognitive, motoric and behavioral development. ${ }^{1}$ In addition, this study shows that the cognitive development score (CAT) is significantly lower among the anemic subjects as compared to the non-anemic counterparts. Thus, this finding strongly suggests to provide iron-rich complementary foods in addition to breastmilk to infants aged 6 months and over to prevent anemia and its concomitant deleterious effect on infant cognitive development.

In this context, our accompanying paper on folate status should be considered. ${ }^{14}$ In both studies the median age of the participating subjects was below 7 months. This may be the main reason why infants had still normal folate and ferritin levels, although the intake of folate and iron were less than recommended. Therefore, the study should be repeated with infants at higher age in order to detect whether blood levels are still in the normal range or, as we would expect, decline with increasing age.

In conclusion, poor hemoglobin levels among infants aged 6-8 months significantly correlate to lower cognitive developmental scores. It is suggested that infants since the age of 6 months should be provided with iron-rich complementary food in addition to the continuation of breastfeeding.

\section{REFERENCES}

1. Harmatz P, Butensky E, Lubin B. Nutritional anemia. In: Nutrition in pediatrics (3rd ed). BC Decker Inc. London. 2003; p830-47.

2. Sekartini R. Prevalensi anemia defisiensi besi pada bayi usia 4-12 bulan di kecamatan Matraman dan sekitarnya, Jakarta Timur. Indonesian. Sari Pediatri. 2005;7(1):2-8.

3. Supariasa IDN, Bakri B, Fajar I. Penilaian Status Gizi Secara Biokimia. In: Penilaian Status Gizi. Jakarta: Indonesian. Penerbit Buku Kedokteran EGC. 2002;p144-53.

4. Walter T, Andraca ID, Chadud P, Perales CG. Iron deficiency anemia: Adverse effects on infant psychomotor development. Pediatric. 1989;84:7-17.

5. Black MM. Iron and zinc supplementation promote motor development and exploratory behavior among Bangladeshi infants. Am J Clin Nutr. 2004;80:903-10

6. Faber M, Kvalsvig JD, Lombard CJ, Benade AJS. Effect of a fortified maize-meal porridge on anemia, micronutrient status, and motor development of infants. Am J Clin Nutr. 2005;82:1032-9.

7. Gibson RE. Assessment of iron status. In: Principle of nutritional assesment. 2nd ed. New York; Oxford University Press. 2005;p443-76.

8. Accardo PJ, Capute AJ. Development of the Capute scales. In: The Capute scales: Cognitive adaptive test/clinical linguistic \& auditory milestone scales (CAT/CLAMS). Paul H. Brookes Publ. Co. 2005; p1-8.

9. World Health Organization. WHO child growth or length/ height for age, weight for age, weight for length, weight for height and body mass index for age: methods and development. World Health Organization; 2006.

10. HemoCue B-haemoglobin photometer operating manual (4th ed), June 1991.

11. Erhardt JG, Estes JE, Pfeiffer CM, Biesalski HK, Craft NE. Combined measurement of ferritin, soluble transferrin receptor (sTfR), retinol binding protein (RBP), c-reactive protein (CRP), and alpha-1 acid glycoprotein (AGP) by an inexpensive, sensitive and simple sandwich ELISA technique. J Nutr. 2004;134(11):3127-32.

12. Madiyono B, Moeslichan MzS, Sastroasmoro S, Budiman I, Purwanto SH. Perkiraan besar sampel. In: Sastroasmoro $\mathrm{S}$, et al. Dasar-dasar metodologi penelitian klinis. 2nd ed. Jakarta: Sagung Seto; 2002; p.259-87.

13. Mitchell MK. Nutrition during infancy. In: Nutrition across the lifespan. 2nd ed. Saunders, USA. 2002; p211-51.

14. Ernawati T, Bardosono S, Sekartini R. Serum folate levels among healthy infants aged 6-8 months: relation to infants' nutritional status indicators and maternal knowledge-attitudepractice. MJI 2010, this edition, accompanying manuscript. 